Kristine Storli Henningsen

Gestaltterapeut, blogger, forfatter og rektor på forfatterskolen.no. Foto: Lise Falch

\title{
Den ydmyke lege
}

\section{Gi meg en lege som aksepterer og deler usikkerheten, heller enn en som er skråsikker.}

For 13 år siden ble jeg syk. Etter å ha spist en kyllingbagett, på en norsk kafé, fikk jeg salmonellainfeksjon. I tre døgn var jeg sikker på at jeg skulle dø. Magekrampene var konstante, jeg hadde skyhøy feber og veien til do føltes som oppstigningen til Galdhøpiggen.

Det gikk heldigvis over. Men et par uker senere begynte det å skje merkelige ting med kroppen. Jeg, som alltid hadde vært myk og vital, begynte å få vondt i leddene. Det verket i hele kroppen og kjentes som å ha influensa. Enkelte av leddene hovnet opp. Hvis jeg satt eller lå for lenge, stivnet kroppen helt. Jeg brukte lang tid på å komme meg opp av sengen, hvis jeg orket å stå opp i det hele tatt, og jeg måtte nærmeste brekke meg selv ut av bilen etter å ha kjørt til butikken.

Det verste var å ikke vite. Det ga rom for katastrofespekulasjoner. Hadde jeg leddgikt? Eller kanskje noe enda skumlere? Jeg gikk til legen. Det er ikke alltid jeg er så flink til det. Men nå gikk jeg til legen, og jeg følte meg liten og redd. I tillegg bekymret jeg meg for økonomien, ettersom jeg var frilanser på denne tiden.

Legen så på meg med et overbærende blikk mens jeg fortalte om tilstanden min. Han skrev ut en sykmelding, som jeg ikke hadde bedt om, og sa jeg hadde influensasmerter. Men jeg har ikke influensa, sa jeg. Og sykmelding trenger jeg ikke, for jeg har ikke fast jobb.
Han mente jeg dramatiserte. At jeg trolig brygget på noe. Så fikk jeg resept på sterke smertestillende medikamenter. De kunne jeg ta når influensaen brøt ut også, sa han, det var høysesong for det nå

Jeg kjørte hjem i mørket og nå hadde jeg ikke bare vondt i kroppen. Jeg hadde vondt i magen også. Hvorfor ble jeg ikke trodd? Jeg tvang meg på jobb. Ingen influensa brøt ut. Og jeg ble ikke bedre. Snart var jeg tom for smertestillende tabletter. Igjen ringte jeg legesenteret og bestilte time.

Denne gangen fikk jeg en ny lege, en ung fyr med et nysgjerrig og vennlig blikk. Han spurte og grov om alt, mens han stadig rynket brynene og slo opp i diverse bøker. Jeg satt ytterst på stolen med stramme skuldre. Ville jeg bli diagnostisert som melodramatisk og influensabryggende en gang til?

Da jeg var ferdig med å fortelle, lente han seg over pulten og kikket på meg. Jeg skal være helt ærlig, sa han. Jeg aner ikke hva som feiler deg. Men dette kan jeg love: Vi skal finne ut av det. Sammen.

Da begynte jeg å gråte. Av lettelse. Noen så meg og ville hjelpe meg. Snart ble jeg lagt inn på sykehus for å ta prøver. Jeg lå der i et døgn mens de stakk meg, igjen og igjen. Og jeg, som ikke kan fordra sprøyter, følte meg rolig og trygg. Alt er bedre enn ikke å vite. Livet er så sårbart. Hvis ikke helsen fungerer, fungerer ingenting annet. Det blir man smertelig klar over når man er syk.

Det viste seg at jeg hadde reaktiv artritt, utløst av salmonellainfeksjonen. Tilstanden kan bli kronisk, men omtrent halvparten av tilfellene går over etter noen måneder.
I hvilken halvdel var jeg? Jeg hadde ingen garantier for å bli frisk. Likevel var jeg lettet. Nå hadde jeg noe å forholde meg til. En diagnose. Det føltes ekstra viktig når sykdommen ikke syntes utenpå. Dessuten var ikke diagnosen dødelig. Jeg hadde livet, selv om det var mer begrenset enn $f \varnothing r$.

Jeg var i den heldige halvdelen. På bryllupsreisen min til Egypt, under en kameltur i ørkenen, kunne jeg formelig kjenne hvordan betennelsen slapp taket i leddene. Kroppen ble gradvis mer bevegelig. Jeg kunne stå rett opp av sengen om morgenen. Jeg trengte ikke smertestillende for å komme meg gjennom dagen.

Ennå setter jeg pris på å ha en kropp som fungerer knirkefritt i det daglige. Jeg har en ny respekt for mennesker som lever med skjulte, kroniske sykdommer. Det føles godt å slippe de bekymrede og medlidende blikkene fra folk rundt meg.

Og jeg vet at det er mer trygt med en lege som innrømmer sin uvitenhet, enn en som er skråsikker på fasiten uten å ha unders $\varnothing$ kt. Det er mye autoritet i en setning som: Jeg vet ikke. Det en ung lege ikke har av erfaring og kunnskap kan tas igjen gjennom nysgjerrighet og engasjement. For meg betydde det alt.

\section{Kistim S.tferningsen}

